\title{
Antibiotic Resistance Pattern and Detection of Enterotoxigenic and Enteroaggregative Strain of Escherichia coli among Foreign Tourist with Traveler Diarrhea in Bali using Uniplex Polymerase Chain Reaction
}

\author{
I Dewa Made Sukrama ${ }^{1 *}$, Anak Agung Wiradewi Lestari², Made Agus Hendrayana ${ }^{1}$, I Ketut Agus Somia ${ }^{3}$ \\ ${ }^{1}$ Department of Microbiology, Faculty of Medicine, Universitas Udayana, Denpasar, Bali, Indonesia; ${ }^{2}$ Department of Clinical \\ Pathology, Faculty of Medicine, Universitas Udayana, Denpasar, Bali, Indonesia; ${ }^{3}$ Department of Internal Medicine, Faculty of \\ Medicine, Universitas Udayana, Denpasar, Bali, Indonesia
}

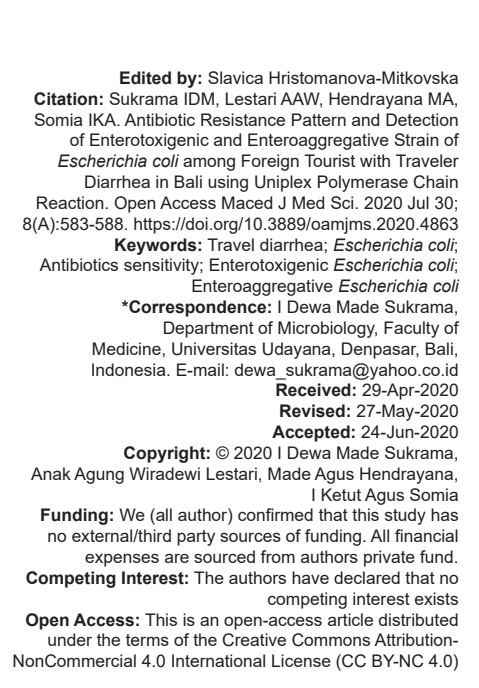

\begin{abstract}
BACKGROUND: As one of the major tourist destinations in Southeast Asia, Bali received millions of foreign tourists each year. Diarrhea consistently placed as the most often experienced health problem among travelers. Traveler diarrhea has various etiologies. The most common was Escherichia coli. The existence of several types of E. coli that are resistant to several antibiotics causes the selection of antibiotics is crucial.

AIM: This preliminary study aims to understand the pattern of antibiotics sensitivity and to detect the presence of enterotoxigenic and enteroaggregative strains of E. coli from fecal samples of foreign tourists with traveler's diarrhea in Denpasar, Bali.

METHODS: A culture examination was carried out to obtain E. coli bacterial colonies. Disk diffusion Kirby-Bauer was carried out for antibiotic sensitivity testing. The confirmed colonies were tested against several common antibiotics, including the recommended first line (ciprofloxacin and azithromycin). Uniplex polymerase chain reaction (PCR) using specific primers conducted to detect the enterotoxigenic E. coli (ETEC) (elt and estA2-4) and enteroaggregative
\end{abstract} E. coli (EAEC) (CVD432) strains.

RESULTS: Among 48 stool culture, 14 (29.2\%) were identified as E. coli colonies. All samples were still sensitive to the antibiotics meropenem, ceftazidime, and cefixime. Despite majority of the samples (78.6\%) still sensitive to ciprofloxacin, large proportion of the samples have developed resistance against the other commonly used antibiotics, doxycycline (70.4\%) and azithromycin (57.1\%). PCR showed that $3(21.4 \%)$ samples shown positive for CVD432 gene, $2(14.3 \%)$ samples positive for the elt gene, and all negative for the estA2-4 gene.

CONCLUSION: An only small proportion of $E$. coli was EAEC or ETEC strain. Although most $E$. coli still sensitive to betalactam antibiotics, a significant proportion had shown resistance against the commonly recommended first-line antibiotics.

\section{Introduction}

Diarrhea is a common illness among travelers [1]. The previous report showed that at least one episode of diarrhea occurs among $20-50 \%$ of travelers. Due to increased trends of overseas travel, it is estimated that 15-20 million travelers will experience diarrhea [2], [3]. Those values are related to different climate, sanitation, and hygiene practices of the destination area as well as the country of origin. Diarrhea not only poses a health problem but also ruins the purpose of the travel such as loss of valuable time, reduced enjoyment, and perhaps increase the spending bill [4]. Moreover, diarrhea could manifest even after the travelers return to their country of origin. Thus, it may also trigger local outbreak [2], [5].

Bali is one of the favorite tourist destinations in the world. Based on data released by Indonesian Statistical Agency, foreign tourist arrivals reached almost 6.3 million people in 2019 [6]. Among another thing, Bali is known for its culinary tourism and its street food, which is popular among overseas tourists. However, there is a caveat, diarrhea always occupies the top three cases of infectious diseases among traveler. However, this problem is nothing special to Bali. In fact, diarrhea is the most common health problem and the major obstacle for foreign tourists when they travel, especially to developing countries [7].

Although the etiological agent of diarrhea varies widely, the most common bacterial pathogen reported was Escherichia coli. E. coli also has few clinical variants associated with the different clinical picture of diarrhea [2], [3], [8]. The previous study by Masyeni et al. [2] showed that $E$. coli was among the primary pathogen among the foreign traveler in Bali. More than $95 \%$ of cases in this study were acute secretory diarrhea, with mild-tomoderate severity. Due to its fast onset, enterotoxigenic $E$. coli (ETEC) and possibly enteroaggregative E. coli (EAEC) strains were suspected to be the main etiologies [2], [4]. 
As previously explained, there are several studies regarding traveler's diarrhea in Bali and most had points out that $E$. coli is the most common pathogen [2], [3], [9]. However, the study that concerns on the specific clinical variant (e.g., ETEC, EAEC, and EHEC) as well its antibiotics resistance pattern was limited at best. This study aimed to provide an initial answer to this question.

\section{Methods}

A cross-sectional study carried out at Microbiology Laboratory of Faculty of Medicine, Universitas Udayana to evaluate diarrheal $E$. coli variant and the corresponding antibiotics sensitivity in December 2019. Sample in this study was feces collected from 48 foreign tourists with traveler diarrhea in Denpasar. Samples were streaked on blood agar and MacConkey agar plate and cultured at $37^{\circ} \mathrm{C}$ for 18-24 h. Colonies then sampled from each plate and further analyzed by Gram staining, catalase test, and biochemistry test. All protocols have been approved by the Ethics Committee of Universitas Udayana/Sanglah General Hospital.

Antibiotic sensitivity testing was conducted according to the Kirby-Bauer disk diffusion based on the Clinical and Laboratory Standards Institute (CLSI) protocol [10]. The choice of antibiotics tested was based on local standard antibiotic recommendation. Resistance tests used eight types of antibiotics, namely, meropenem, gentamicin, doxycycline, ceftazidime, cefixime, ciprofloxacin, amikacin, and azithromycin. Antibiotic sensitivity was categorized into sensitive, intermediate, and resistant bacterial isolates for each antibiotic tested according to the measured inhibition zone diameter. The cutoff of the inhibition zone was based on the most recent guideline published by CLSI [10].

Table 1: List of primers and the measures used in the study [11]

\begin{tabular}{|c|c|c|c|c|}
\hline Target Gen & Primer design & Primer & $\begin{array}{l}\text { PCR } \\
\text { product (bp) }\end{array}$ & $\begin{array}{l}\text { E. coli } \\
\text { variant }\end{array}$ \\
\hline CVD432 & $\begin{array}{l}\text { CTGGCGAAAGACTGTATCAT } \\
\text { AAATGTATAGAAATCCGCTGTT }\end{array}$ & pCVD432 & 630 & EAEC \\
\hline Elt & $\begin{array}{l}\text { ACGGCGTTACTATCCTCTC } \\
\text { TGGTCTCGGTCAGATATGTG }\end{array}$ & LT & 273 & ETEC \\
\hline estA2-4 & $\begin{array}{l}\text { TTCACCTTTCCCTCAGGATG } \\
\text { CTATTCATGCTTTCAGGACCA }\end{array}$ & Sth & 120 & ETEC \\
\hline
\end{tabular}

ETEC: Enterotoxigenic Esched

DNA isolation was carried out using a boiling technique. Sample $(10 \mathrm{ml})$ dissolved in TE buffer was boiled for $10 \mathrm{~min}$ at $99^{\circ} \mathrm{C}$. Polymerase chain reaction (PCR) process was started after pure DNA mixed with KAPA2G Fast HotStart $\mathrm{PCR}^{\mathrm{TM}}$ reaction mix (includes DNA polymerase $5 \mathrm{U} / \mu \mathrm{L}$, buffer with $\mathrm{MgCl}_{2}$, dNTP Mix) and the primers (for ETEC and EAEC). The final volume yields $10 \mu \mathrm{L}$, which contains $0.8 \mu \mathrm{l}$ DNA template, $5 \mu \mathrm{L}$ reaction mix, $3.2 \mu \mathrm{L} \mathrm{H}_{2} \mathrm{O}, 0.5 \mu \mathrm{L}$ forward primer, and $0.5 \mu \mathrm{L}$ reward primer. PCR process conducted
Table 2: PCR protocol/program used to detect ETEC and EAEC genes

\begin{tabular}{lllll}
\hline Primer & Program & Temperature & Time & Cycle \\
\hline pCVD432 & Pre-denaturation & $95^{\circ} \mathrm{C}$ & $3 \mathrm{~min}$ & $\times 1$ \\
estA2-4 & Denaturation & $95^{\circ} \mathrm{C}$ & $30 \mathrm{~s}$ & $\times 35$ \\
elt & Annealing & $55^{\circ} \mathrm{C}$ & $30 \mathrm{~s}$ & \\
& Extension & $72^{\circ} \mathrm{C}$ & $1 \mathrm{~min}$ & \\
\multicolumn{4}{l}{ PCR: Polymerase chain reaction, EAEC: Enteroaggregative Escherichia coli, ETEC: Enterotoxigenic } \\
Escherichia coli.
\end{tabular}
Escherichia coli.

on Biometra PCR Thermal cycler. The primers were referenced from Tobias et al. and shown in Table 1 [11]. PCR protocol is summarized in Table 2. Electrophoresis was performed by inserting PCR products (each $2 \mu \mathrm{L}$ ) into $1 \%$ electrophoresis gel created by mixing $0.7 \mathrm{~g}$ agarose and $70 \mathrm{~mL}$ of $\times 1$ Tris-borate-EDTA for $60 \mathrm{~min}$. The gel that has been completed through the running stage then inserted into the Bio-Rad Gel-Doc.

\section{Results}

Among 48 diarrhea stool samples that were identified as positive for bacterial cause, 14 samples $(29.2 \%)$ consistent with the characteristics of $E$. coli. The result of antibiotics sensitivity tests is shown in Table 1 and Figure 1.

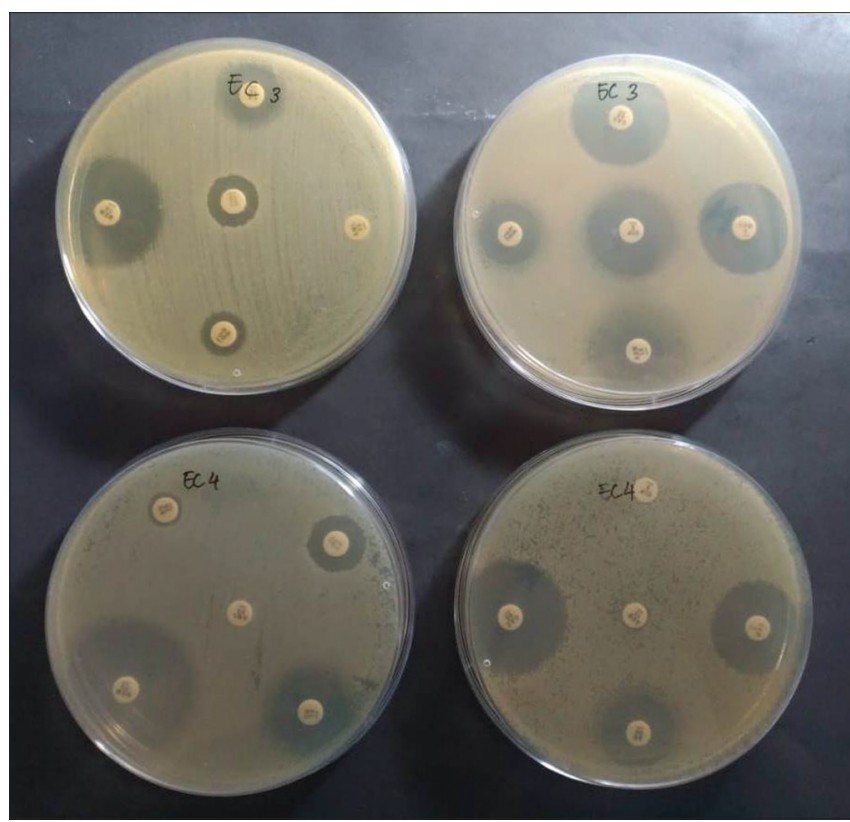

Figure 1: The sample of Escherichia coli sensitivity test of samples code EC3 and EC4 using the disk diffusion (Kirby-Bauer). Clear circle around the antibiotic paper disk is the antibiotic inhibition zone

We tested 14 samples of E. coli against eight different antibiotics from several classes (Table 3). Three antibiotics, meropenem, ceftazidime, and cefixime, were shown preserved sensitivity against all samples. Meanwhile, ciprofloxacin sensitive in 11 samples $(78.6 \%)$, resistant two samples $(14.3 \%)$ and intermediate in one sample $(7.1 \%)$. Gentamicinsensitive in eight samples $(57.1 \%)$, resistant in four 
Table 3: The result of the Escherichia coli sensitivity test

\begin{tabular}{|c|c|c|c|c|c|c|c|c|}
\hline & Meropenem & Gentamicin & Doxycycline & Ceftazidime & Cefixime & Ciprofloxacin & Amikacin & Azithromycin \\
\hline EC1 & $S$ & $\mathrm{~S}$ & $\mathrm{R}$ & S & $\mathrm{S}$ & S & $\mathrm{R}$ & $\mathrm{R}$ \\
\hline EC2 & S & $\mathrm{R}$ & $\mathrm{R}$ & S & $\mathrm{s}$ & S & I & $\mathrm{R}$ \\
\hline EC3 & $\mathrm{S}$ & 1 & $\mathrm{R}$ & $\mathrm{S}$ & $\mathrm{s}$ & $\mathrm{S}$ & 1 & $\mathrm{R}$ \\
\hline EC4 & $\mathrm{s}$ & $\mathrm{s}$ & $\mathrm{R}$ & $\mathrm{s}$ & $\mathrm{s}$ & $\mathrm{R}$ & $\mathrm{s}$ & $\mathrm{R}$ \\
\hline EC5 & S & 1 & S & S & $\mathrm{s}$ & S & S & $\mathrm{R}$ \\
\hline EC6 & S & $\mathrm{s}$ & S & S & $\mathrm{s}$ & S & I & S \\
\hline EC7 & $\mathrm{S}$ & S & $\mathrm{R}$ & S & $\mathrm{s}$ & $\mathrm{R}$ & S & $\mathrm{R}$ \\
\hline EC8 & $\mathrm{s}$ & S & $\mathrm{s}$ & $\mathrm{s}$ & $\mathrm{s}$ & S & $\mathrm{s}$ & S \\
\hline EC9 & S & S & S & S & $\mathrm{s}$ & s & 1 & S \\
\hline EC10 & S & $\mathrm{s}$ & $\mathrm{R}$ & S & $\mathrm{s}$ & S & $\mathrm{s}$ & S \\
\hline EC11 & S & S & $\mathrm{R}$ & S & $\mathrm{s}$ & S & S & S \\
\hline EC12 & $\mathrm{s}$ & $\mathrm{R}$ & $\mathrm{R}$ & S & $\mathrm{s}$ & 1 & 1 & S \\
\hline EC13 & $\mathrm{s}$ & $\mathrm{R}$ & $\mathrm{R}$ & S & $\mathrm{s}$ & $\mathrm{s}$ & 1 & $\mathrm{R}$ \\
\hline EC14 & S & $\mathrm{R}$ & $\mathrm{R}$ & S & $\mathrm{s}$ & S & $\mathrm{R}$ & $\mathrm{R}$ \\
\hline
\end{tabular}

Antibiotic sensitivity test result annotated as $\mathrm{S}$ (sensitive), I (intermediate), $\mathrm{R}$ (resistance), based on CLSI cutoff.

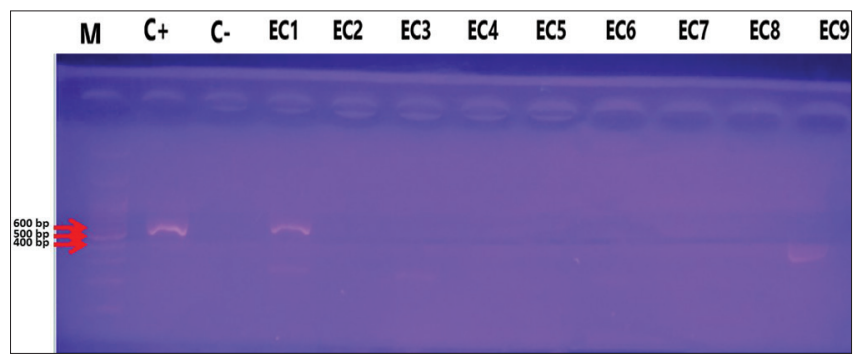

Figure 2: Electrophoresis image of CVD432 target gene (630 bp) of the samples no. 1-10. M: Marker, C+: Positive control, C-: Negative control, EC: Escherichia coli sample, bp: Base pairs

samples (28.6) and intermediate in two samples (14.3). Amikacin, azithromycin, and doxycycline have shown sensitivity in only less than half of the samples. Furthermore, doxycycline and azithromycin were the two highest antibiotics that yield resistant results.

The electrophoresis of the PCR products is shown in Figures 2-7. Figures 2 and 3 show that there were three samples (EC1, EC12, and EC14) from 14 samples $(21.4 \%)$ that show the expected band (630 bp) of the CVD432 target gene. Figures 4 and 5 show that two samples (EC1 and EC8) from 14 samples (14.3\%) showed a band at around $273 \mathrm{bp}$, which represent the elt gene. Meanwhile, on Figures 6 and 7, no sample shows the expected band of estA2-4 gene (140 bp).

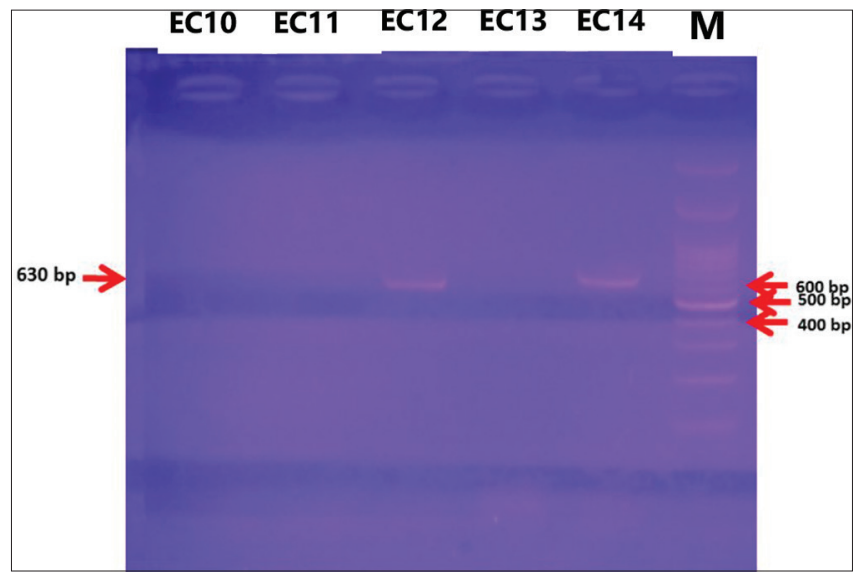

Figure 3: Electrophoresis image of CVD432 target gene (630 bp) of the samples no. 10-14. M: Marker, C+: Positive control, C-: Negative control, EC: Escherichia coli sample, bp: Base pairs

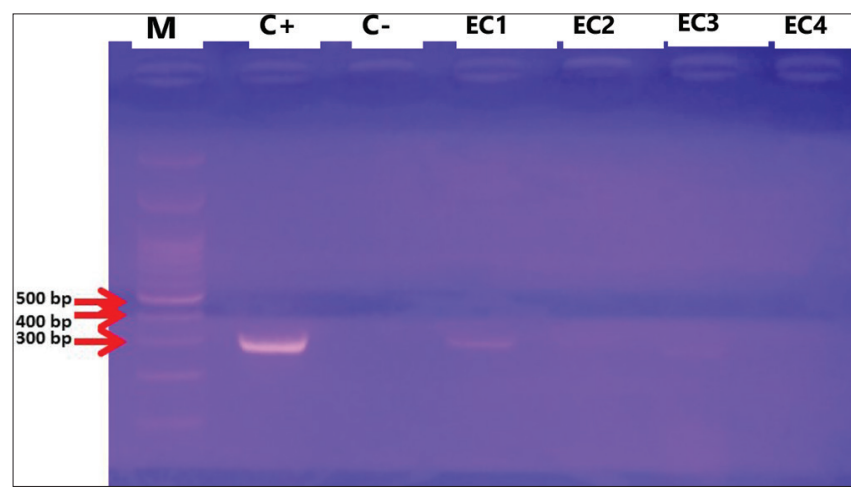

Figure 4: Electrophoresis image of elt target gene (273 bp) of the samples no. 1-4. M: Marker, C+: Positive control, C-: Negative control, EC: Escherichia coli sample, bp: Base pairs

\section{Discussion}

Broadly speaking, traveler's diarrhea is typically a self-limited condition. Although it can lead to dehydration and in severe cases, it also leads to significant complications [3]. Most of the time, healthcare provider will prescribe antibiotics along with advice and other supportive treatment [12]. Most expert and

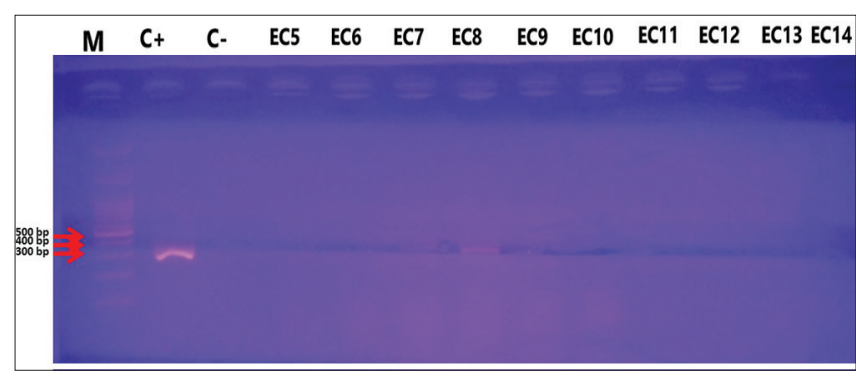

Figure 5: Electrophoresis image of elt target gene (273 bp) of the samples no. 5-14. M: Marker, C+: Positive control, C-: Negative control, EC: Escherichia coli sample, bp: Base pairs

textbooks recommend ciprofloxacin as the first-line treatment, except in the cases with Campylobacter species, is the suspected etiology [1], [12], [13]. For this reason, azithromycin was preferable than 


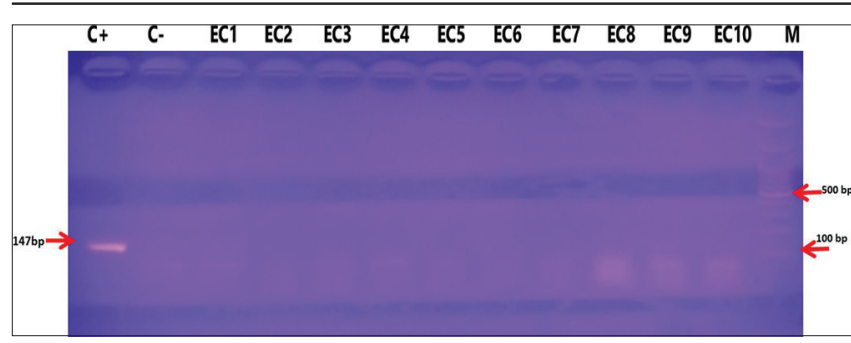

Figure 6: Electrophoresis image of estA2-4 target gene (147 bp) of the samples no. 1-10. M: Marker, C+: Positive control, C-: Negative control, EC: Escherichia coli sample, bp: Base pairs

fluoroquinolones for travelers' diarrhea in a particular country of Asia with a high prevalence of Campylobacterrelated traveler diarrhea (mostly Southeast Asian country) [13], [14].

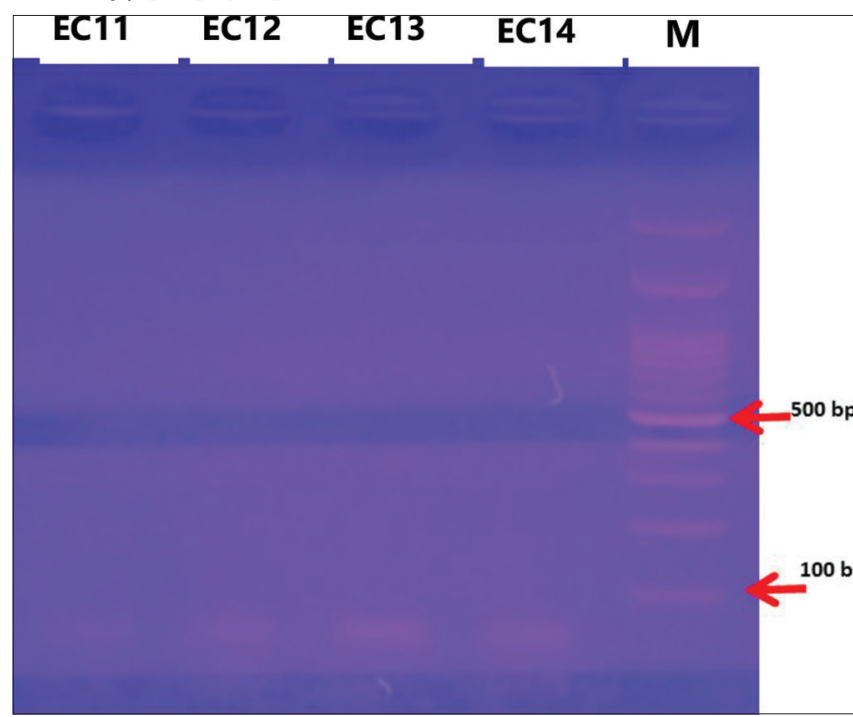

Figure 7: Electrophoresis image of estA2-4 target gene (147 bp) of the samples no. 11-14. M: Marker, C+: Positive control, C-: Negative control, EC: Escherichia coli sample, bp: Base pairs

Many bacterial, viral, and parasitic infections could be the cause of diarrhea, although bacterial (enteric bacteria) sources represent the most frequent etiology [12], [15]. The previous literature has shown that one of the common bacterial causes is $E$. coli and specifically the ETEC. Estimates have shown that this particular variant of $E$. coli is responsible for nearly $30 \%$ of the cases [3], [16]. Although, the pattern of the common cause of traveler's diarrhea varied heavily by region. Some studies have shown that Campylobacter species was the most common pathogen in Southeast Asia [13], [14], [15]. The previous study in Bali [2] has shown that $E$. coli was the most common bacterial etiology. The study also has shown that the most common clinical picture of diarrhea was acute onset of watery stool with mild-to-moderate severity. This clinical picture was theoretically consistent with diarrhea caused by ETEC and perhaps the EAEC [2], [12].

However, this study findings point a slightly different direction. Based on the PCR results, only 3 samples $(21.4 \%)$ were positive for the CVD432, which code for master regulator of EAEC plasmid virulence factors (AggR). Two samples (14.3\%) shown positive for elt gene, which code for the ETEC labile toxin (LT).
Meanwhile, no sample has shown a band at the expected length of the estA2-4 target gene, which encodes the ETEC heat-stable enterotoxins [11]. One interesting finding was that one sample (sample EC1) shown positive for CVD432 and elt gene. This finding perhaps reflects that one variant (whether EAEC or ETEC) that has the other virulence genes. Although both virulence factors were based on the plasmid, which was likely transferable, we suspect that these samples were EAEC that acquired the LT plasmid gene [17]. This argument was supported by the previous finding by Vila et al. that among 23 fecal samples of traveler diarrhea with confirmed EAEC, 14 of those carried a least one other virulence genes (i.e., LT, EAST, ShET1, ShET2, etc.). Among those 14, one carried the part of the LT gene [18]. EAEC strains known as heterogeneous as previous studies reveal that it shares potential virulence factor as another variant of diarrheal $E$. coli. EAEC strains have shown an increased trend as cause of human diarrhea, including traveler diarrhea [18], [19]. Thus, we expect that it will deserve increased attention among the research community to delineate the nature of its virulence further.

The cephalosporin antibiotics, ceftazidime and cefixime, showed sensitivity in all samples (100\%). Although, it is contrary to the popular trend of increased resistance of $E$. coli and another Gram-negative bacterium to a broad spectrum and $\beta$-lactams [20], [21]. Cephalosporin antibiotics were commonly used for Gram-negative community-acquired infection [22]. However, these antibiotics rarely recommended for traveler diarrhea, except in cases caused by Shigella $\mathrm{sp}$. [23]. Meropenem, the representative of carbapenem class, was shown sensitivity against all isolates. This is consistent with the expectation of this class of antibiotics that usually recommended for the last resort. It is rarely used for first-line treatment of traveler diarrhea, thus if any isolates shown a resistant or even intermediate result, should warrant urgent attention. Fluoroquinolone, represented by ciprofloxacin, shown relatively good efficacy. This result has shown that the recommended first-line treatment might still effective in majority of the cases. The aminoglycoside antibiotics tested in this study, gentamycin and amikacin, shown an overall moderate level of efficacy as it is still shown sensitivity in roughly half of the isolates. The surprising result came from the doxycycline and azithromycin. In contrast to ciprofloxacin, azithromycin as the alternative for first-line treatment was shown high rate of resistant. Although somewhat predictable, doxycycline has the highest resistant rate among others. This finding is common, as many recent literatures report widespread resistance. The possible explanation for the high rate of resistance to doxycycline is the widespread use as travelers' diarrhea prophylaxis in past. Fortunately, It is not recommended anymore due to the resulted widespread resistance. Moreover, the efficacy of prophylaxis itself is still in debate [12], [15].

Most isolates were resistant for both antibiotics perhaps reflect the prescribing pattern of health-care 
provider. A typical recommended doses of azithromycin are $500 \mathrm{mg}$ daily for 3 days or a single dose of $1000 \mathrm{mg}$ [24], [25]. Recommendations for many other infectious diseases were roughly similar. Thus, both factors may be viewed as the most convenience regimen and brought the spotlight for traveler diarrhea and not to mention for other infections as well. Furthermore, single or few doses needed and a sense of powerful drugs makes it as the choice of self-treatment among travelers [12], [24]. The other possible explanation is Bali geographically sits on Southeast Asian Archipelago, and most literature recommended azithromycin as the first line [12], [15]. This condition may drag azithromycin to the brink of antibiotics abuse and thus a high rate of resistant in community-acquired infection.

The authors realized that this study has several limitations. The sample size was small and the extend of the test was limited. Due to a limited budget and a primary intend of preliminary studies, this study only investigates the possibility of ETEC and EAEC variants among many possible traveler diarrhea etiologies. This decision was grounded based on the previous study in Bali that shown a clinical picture that consistent with those two variants. Moreover, disk diffusion KirbyBauer methods also come with its limitation [26], [27]. The authors strongly encourage further research with a larger sample size and better methodologies.

\section{Conclusion}

Only a small proportion of E. coli that was EAEC and ETEC strain responsible for traveler diarrhea in Bali. Although most $E$. coli still sensitive to beta-lactam antibiotics, a significant proportion had shown resistance against the commonly recommended first-line antibiotics.

\section{Acknowledgments}

The authors would like to acknowledge the honorable staff of the Microbiology Department of Universitas Udayana that lends their support for this study. The authors also thank Ida Bagus Amertha Putra Manuaba, I Putu Yuda Prabawa and KadekAdit Wiryadana for the suggestion and improvement in manuscript writing.

\section{Authors' Contributions}

study.

\section{References}

1. Keystone JS, Kozarsky PE. Health recommendations for international travel. In: Kasper DL, Fauci AS, Hauser SL, Longo DL, Jameson JL, Loscalzo J, editors. Harrison's Principles of Intern Medicine. $19^{\text {th }}$ ed. New York: McGraw-Hill Education; 2015. p. 796-7.

2. Masyeni S, Sukmawati $H$, Paramasatiari L, Aryastuti A Somia KA, Kambayana G, et al. Diarrhea among international travelers in Bali-Indonesia: Clinical and microbiological finding. Int J Travel Med Glob Health. 2017;5(3):84-8.

3. Dunn N, Okafor CN. Travelers Diarrhea. Treasure Island, FL: StatPearls Publishing; 2020

4. Kass B. Traveller's diarrhoea. Aust Fam Physician. 2005;34(4):243-7.

PMid: 15861744

5. Tsai HT, Jiang DD, Tung HP, Su CP, Chien YS, Chuang JH. A cluster of diarrhea in a tourist group to Bali, Indonesia. Taiwan Epidemiol Bull. 2010;26(20):348-63.

6. Badan Pusat Statistik Provinsi Bali. Number of Foreign Visitor to Indonesia and Bali, 1969-2019. Available from: https://www.bali. bps.go.id/statictable/2018/02/09/28/jumlah-wisatawan-asingke-bali-dan-indonesia-1969-2019.html. [Last accessed on 2020 Apr 25]. https://doi.org/10.2307/3350805.

7. Ryan ET, Wilson ME, Kain KC. Illness after international travel. N Engl J Med. 2002;347(7):505-16. PMid:12181406

8. Sumadewi KT, Narendrakomaranatha A, Lalita E, Rusni W, Pratiwi AE, Witari PD, et al. Travel related infection among international travellers visiting clinics at Ubud Bali. In: IOP Conference Series: Materials Science and Engineering. United Kingdom: Institute of Physics; 2018. p. 1-5. Available from: https://www.iopscience.iop.org/article/10.1088/1757899X/434/1/012314/pdf. [Last accessed on 2020 Jan 11].

9. Sohail A, McGuinness SL, Lightowler R, Leder K, Jomon B, Bain CA, et al. Spectrum of illness among returned Australian travellers from Bali, Indonesia: A 5-year retrospective observational study. Intern Med J. 2019;49(1):34-40. https://doi. org/10.1111/imj.13993 PMid:29869360

10. CLSI. M02-A12 Performance Standards for Antimicrobial Disk. Vol. 32. United States: CLSI; 2015. p. 1-96 p.

11. Tobias J, Vutukuru SR. Simple and rapid multiplex PCR for identification of the main human diarrheagenic Escherichia coli. Microbiol Res. 2012;167(9):564-70. https://doi.org/10.1016/j. micres.2011.11.006

PMid:22192837

12. Hill DR, Ryan ET. Management of travellers' diarrhoea. BMJ. 2008;337(7674):863-7.

PMid:9664200

13. Shah N, DuPont HL, Ramsey DJ. Global etiology of travelers diarrhea: Systematic review from 1973 to the present. Am J Trop Med Hyg. 2009;80(4):609-14. https://doi.org/10.4269/ ajtmh.2009.80.609

PMid:19346386

14. Lääveri T, Vilkman K, Pakkanen SH, Kirveskari J, Kantele A. A prospective study of travellers' diarrhoea: Analysis of pathogen findings by destination in various (sub)tropical regions. Clin Microbiol Infect. 2018;24(8):908. https://doi.org/10.1016/j. cmi.2017.10.034

PMid:29133155

15. Diptyanusa A, Ngamprasertchai T, Piyaphanee W. A review of antibiotic prophylaxis for traveler's diarrhea: Past to present. Trop Dis Travel Med Vaccines. 2018;4:14. https://doi. 
org/10.1186/s40794-018-0074-4

16. Connor BA, Rogova M, Whyte O. Use of a multiplex DNA extraction PCR in the identification of pathogens in travelers' diarrhea. J Travel Med. 2018;25(1):087. https://doi.org/10.1093/ jtm/tax087

PMid:29394385

17. Johnson TJ, Nolan LK. Pathogenomics of the virulence plasmids of Escherichia coli. Microbiol Mol Biol Rev. 2009;73(4):750-74.

18. Vila J, Vargas M, Henderson IR, Gascón J, Nataro JP. Enteroaggregative Escherichia coli virulence factors in traveler's diarrhea strains. J Infect Dis. 2000;182(6):1780-3. https://doi. org/10.1086/317617

PMid:11069254

19. Olson S, Hall A, Riddle MS, Porter CK. Travelers' diarrhea: Update on the incidence, etiology and risk in military and similar populations-1990-2005 versus 2005-2015, does a decade make a difference? Trop Dis Travel Med Vaccines. 2019;5(1):115. https://doi.org/10.1186/s40794-018-0077-1 PMid:30675367

20. Russo T, Johnson J. Diseases caused by gram-negative enteric bacili. In: Kasper DL, Fauci AS, Hauser SL, Longo DL, Jameson JL, Loscalzo J, editors. Harrison's Principles of Intern Medicine. $19^{\text {th }}$ ed. New York: McGraw-Hill Education; 2015. p. 1146-58.

21. Ayatollahi J, Shahcheraghi SH, Akhondi R, Soluti S. Antibiotic resistance patterns of Escherichia coli isolated from children in shahid sadoughi hospital of Yazd. Iran J Pediatr Hematol Oncol.
2013;3(2):78. https://doi.org/10.31254/jmr.2017.3401

PMid:24575275

22. Pitout JD. Extraintestinal pathogenic Escherichia coli: An update on antimicrobial resistance, laboratory diagnosis and treatment. Expert Rev Anti Infect Ther. 2012;10(10):1165-76. Available from: https://doi.org/10.1586/eri.12.110 PMid:23199402

23. Bruzzese E, Giannattasio A, Guarino A. Antibiotic treatment of acute gastroenteritis in children. F1000Res. 2018;7:193. https:// doi.org/10.12688/f1000research.12328.1 PMid:29511533

24. DuPont HL. Azithromycin for the self-treatment of traveler's diarrhea. Clin Infect Dis. 2007;44(3):347-9.

25. Leder K. Advising travellers about management of travellers' diarrhoea. Aust Fam Physician. 2015;44(1):34-7. https://doi. org/10.1111/j.1365-2036.2008.03647.x PMid:25688957

26. Wiryadana KA, Pinatih KJ, Hendrayana MA. Uji daya hambat kombinasi siprofloksasin dengan obat non-antibiotik artesunat, diklofenak dan loperamid terhadap pertumbuhan isolat klinis Escherichia Coli. E J Med Udayana. 2019;8(1):157. https://doi. org/10.14710/jnc.v2i2.2754

27. Jorgensen $\mathrm{JH}$, Ferraro $\mathrm{MJ}$, Jorgensen $\mathrm{JH}$, Ferraro $\mathrm{MJ}$. Antimicrobial susceptibility testing: A review of general principles and contemporary practices. Clin Infect Dis. 2009;49(11):1749-55. https://doi.org/10.1086/647952 